\title{
Biological Control of Tomato Damping-off Disease Caused by Rhizoctonia solani Kuhn
}

\author{
${ }^{1}$ Amer, M. A., ${ }^{1}$ S. M. Shama, ${ }^{2}$ I. I. Abou-El-Seoud, ${ }^{1}$ Ahmed I. A. Heflish, ${ }^{1}$ M. \\ A. Bresam \\ ${ }^{1}$ Department of Agricultural Botany (Plant Pathology), Faculty of Agriculture (Saba- \\ Basha), Alexandria University, Egypt. \\ ${ }^{2}$ Department of Soil and Agricultural Chemistry, Faculty of Agriculture (Saba-Basha), \\ Alexandria University, Egypt. \\ Corresponding author: Mostafa Amer, E-mail: maaamer@hotmail.com
}

\begin{abstract}
Tomato Damping-off disease caused by Rhizoctonia solani is considered as one of the most destructive diseases in Egypt. Effect of some biological control agents such as Trichoderma viride, arbuscular mycorrhiza (AM) and Bacillus subtilis, at seven different mixed treatments, was tested for their ability to control in tomato plants against the disease. According to varietal responses test, all the tested isolates of $R$. solani showed Damping-off symptoms on six tested cultivars; however, they considerably varied in percentages of pre-emergency and post-emergency symptoms. Freda was more susceptible than Alesa cultivar, which was relatively resistant. The combination of $A M$, with $T$. viride, and $B$. subtilis was the most effective in decrease the infection rate of the tested biological control, compared with the other treatments.
\end{abstract}

Kew words: Rhizoctonia solani, Trichoderma viride, Bacillus subtilis, Arbuscular mycorrhiza.

\section{INTRODUCTION}

Tomato (Lycopersicon esculentum L.) is considered one of the most important vegetable crops in Egypt that attack by many soil-borne fungal pathogens (Morsy et al., 2009). Fusarium solani and R. solani are the most important soil-borne fungal pathogens, which develop in cultured and noncultured soils, causing the symptoms of damping-off and root rot diseases to wide range of vegetable and crop plants including tomato (Abu-Taleb et al., 2011). The incidence of damping-off was increased from 19 to $90 \%$ with increasing the inoculums level of $R$. solani, while the incidence of root rots caused of 10 to $80 \%$ losses in different vegetables (Hadwan and Khara, 1992). The tomato cultivars were classified into three groups of resistant, tolerant and susceptible according to their reaction to Fusarium and Rhizoctonia infection (Moustafa and Khafagi, 1992). Limited information is available on its sustainable management and is generally treated by chemical applications. Overuse of the chemical may result in environmental, human health and pest resistance problem. The increasing awareness of fungicide-related hazards has emphasized the need for adopting biological methods as an alternative disease control method, which is also ecofriendly (Khare et al., 2010).

Biological control is an efficient and environmentally friendly way to prevent damping-off disease. Many microbial species such as Trichoderma spp. used to control R. solani (Hafez et al., 2013). Mycorrhizal associations are influenced by abiotic and biotic factors, including climate, soil conditions and the identity of host plants. However, the effect of environmental conditions on orchid mycorrhizal associations remains poorly understood (Mujica et al., 2016). Inoculation of carob plants, Ceratonia siliqua, with Endomycorrhizae has a significant effect on the growth of these plants. Indeed, the mean values of the 
length $(61 \mathrm{~cm})$ and weight $(57.85 \mathrm{~g})$ of the aerial part; the length $(53.87 \mathrm{~cm})$ and weight $(53.27 \mathrm{~g})$ of the root system, stem diameter $(1.15 \mathrm{~cm})$ and the number of sheets (139.12) inoculated plants with Mycorrhizal AM are higher than those inoculated simultaneously with the Endomycorrhiza and Trichoderma harzianum (Tcomp) respectively, $56.12 \mathrm{~cm}, 44.47 \mathrm{~g}, 42.25 \mathrm{~cm}, 39.82 \mathrm{~g}, 1.03 \mathrm{~cm}$, 130.37 and also those only inoculated with $T$. harzianum. Moreover, the frequency $(98 \%)$ and the intensity $(73 \%)$ of Mycorrhization being higher in the level of the root seedlings inoculated only with Endomycorrhiza that those coinoculated with Mycorrhizae AM and T. harzianum, respectively $75 \%$; $56 \%$ (Zouheir et al., 2016).

Thus, the aim of this work was collecting $R$. solani isolates from different Plant Pathology laboratories, then check their identification by molecular technique, testing their pathogenicity, studying the varietal responses of different tomato cultivars to the disease incidence. Study the efficacy of some biological control agents either single or in combination applications on tomato plants to provide some major resistance subsequently reducing pre- and postemergence damping-off disease and infection caused by $R$. solani, and hence provide new strategies to control the damping-off disease of tomatoes.

\section{MATERIAL AND METHODS}

\section{Sources of fungal isolates}

One isolate of tomato damping-off pathogen $R$. solani was isolated from diseased tomato seedlings from Alexandria governorate and 5 isolates were brought from Plant Pathology Laboratories i.e; Agricultural Research Center, Beni Suef, Al Beheira, Al Monufia, Kafr Elsheikh and Faiyum.

\section{Isolation, purification and identification of $\boldsymbol{R}$. solani}

Isolation was carried out from fresh tomato seedlings, showing Dampingoff symptoms. Seedlings were carefully washed in running tap water to remove the adhering particles, then surface sterilized with $95 \%$ ethyl alcohol. The infected parts were cut into small pieces by using sterilized scalpel at the zone of infection. The stem pieces were washed several times in sterile distilled water and dried between two sterilized filter papers, then transferred to the surface of plain agar medium in Petri dishes and incubated at $25{ }^{\circ} \mathrm{C}$ for $4-7$ days. The developed mycelium was carefully transferred to slant potato dextrose agar (PDA) medium. The growing fungus was kept for subsequent purification and identification Dhingra and Sinclair (1985).

Purification of $R$. solani was carried out, using both single hyphal tip techniques (Hansen, 1926). Pure cultures of the obtained isolates were identified in laboratory on the basis of cultural and microscopic characteristics according to Booth (1971), Alexopoulos and Mims (1979), Ellis (1971) and Barnett and Hunter (1987). Pure cultures of the obtained fungal isolates were then transferred to PDA medium slants and kept at $5^{\circ} \mathrm{C}$ for further studies. 


\section{DNA isolation}

Mycelial cultures of $15 R$. solani isolates were grown in potato dextrose broth media for 5 days at $28^{\circ} \mathrm{C}$. Mycelia were harvested and DNA was extracted using CTAB method used by Murray and Thompson (1980).

\section{Molecular characterization using ITS}

Molecular identification of $R$. solani cultures were carried out based on conserved ribosomal internal transcribed spacer (ITS) region. We amplified the ITS regions between the small nuclear 18S rDNA and large nuclear 28S rDNA, including 5.8S rDNA using universal primer pairs ITS1 (5" -TCCGTA GGTGAACCTGCGG-3") and ITS4 (5" -TCCTCCGCTTATT GATATGC-3") (White et al. 1990). Amplification was performed on a Thermal Cycler with 25 reaction mixtures containing $2.5 \mu \mathrm{l}$ of $10 \mathrm{X}$ buffer $(10 \mathrm{mM}$ Tris- $\mathrm{HCl}, \mathrm{pH} 8.8) ; 2.5$ $\mathrm{mM} \mathrm{MgCl}$; 2 mM each of dNTP; 25 pmol ml1 primer (each of ITS-1 and ITS-4); $1 U$ of Taq DNA Polymerase; $60-100$ ng genomic DNA. The amplification cycle consists of an initial denaturation at $95 \mathrm{C}$ for $2 \mathrm{~min}$ followed by 35 cycles at $94 \mathrm{C}$ for $30 \mathrm{~s}, 56 \mathrm{C}$ for $1 \mathrm{~min}$, and $72 \mathrm{C}$ for $2 \mathrm{~min}$ and a final extension at $72 \mathrm{C}$ for 10 min. Amplified PCR products were separated on an agarose gel $(1.5 \% \mathrm{w} / \mathrm{v})$ in 1X TAE buffer. They were then eluted, and further sequencing was carried out.

\section{ITS data analysis}

The ITS nucleotide sequences for each isolate were then compared to those in the public domain databases NCBI (National Center for Biotechnology information; www.ncbi.nih.gov) using Basic Local Alignment Search Tool for Nucleotide Sequences (BLASTN). Alignment of ITS DNA sequences was done using Clustal W program (Vincelli and Tisserat, 2008).

\section{Varietal responses}

In order to check varietal response throughout this study, six isolates of $R$. solani that varied in aggressiveness obtained from diseased tomato plants were used. $R$. solani isolates were selected according to their mycelia and sclerotia characteristics. Six isolates were individually tested for their pathogenicity on Alesa, Alia, Princesa, Jana, Alex. and Frida tomato cultivars under greenhouse conditions. Pots capacity $1 \mathrm{~kg}$ were sterilized by immersing them in 5\% formalin solution, then left 3 weeks to allow formaldehyde evaporation and filled with autoclaved aerated clay soil. Fungal inocula were grown on sterilized PD medium in $250 \mathrm{ml}$ flasks for 2 weeks at $18^{\circ} \mathrm{C}$. Soil infestation with the tested pathogen was carried out using the inoculum which was mixed thoroughly with the soil in each, watered and left for one week to secure establishment of the inoculated fungi. Control pots were filled with the same soil mixed and watered. Seeds of tomato cultivars were surface sterilized using $1 \%$ sodium hypochlorate solution for 2 minutes, washed with sterilized water, dried and sown at a depth of $2 \mathrm{~cm}$ and watered regularly 7 days under greenhouse conditions. The number of pre-emergence and post-emergence damping-off seedlings were recorded 10-30 days after planting. 


\section{Effect of antagonistic fungi on the disease incidence caused by $R$. solani}

Plastic pots were filled with autoclaved sandy loam soil as previously mentioned. Sowing was carried out 8 days after inoculation. Five seeds of vicar genotype were planted ( 3 replicates). Before planting, seeds were surface sterilized by dipping in $1 \%$ sodium hypochlorite for 2 min., washed with distilled water, then dried under laminar flow. Seeds coated were performed by wetting them with sterile water containing molasses, air dried and then placed on the surface of 14 days-old culture of

antagonistic fungi in Petri plates in that conidia were abundant. Control treatment was done by soaking seeds in distilled water. Data of the disease incidence was recorded after 15 and 45 days.

\section{Biocontrol agents}

Certain antagonistic microorganisms, $T$. viride, $A M$ and $B$. subtilis were used in greenhouse experiments to study their effectiveness as biological control against the highly pathogenic isolate of $R$. solani.

\section{Source and preparation of inoculate \\ Preparation of pathogen isolate}

Virulent Isolates of $R$. solani were selected from pathogenicity tests. Mycelium suspension was prepared by growing isolate in wheat grain medium and incubated at $25-28{ }^{\circ} \mathrm{C}$ for 15 days.

\section{Source Mycorrhiza}

Arbuscular mycorrhiza (Glomus intraradices) was used in this experiment. The soil was mixed with $20 \mathrm{ml}$ mycorrhiza one week before planting as described by Malibari et al. (1990). Also, $10 \mathrm{ml}$ inoculums were added with the seeds at sowing time. The arbuscular mycorrhiza (AM) was obtained from Germany and activated in the Soil Microbiology Lab - Soil and Agricultural Chemistry Department, Faculty of Agriculture, Saba Basha, Alexandria University, Alexandria, Egypt.

\section{Soil preparation}

The clay soil was used in the present experiment. Soil samples each weighing $1000 \mathrm{~g}$ were separately filled into plastic pots $(15 \mathrm{~cm})$. Five seeds of tomato were sown in each pot. The NPK, 20:20:20 fertilizer was added at two equal doses ( 20 days and 34 days after sowing) at rate $92 \mathrm{mg} \mathrm{N} / 50 \mathrm{ml}$ water for each pot. The biocontrol AM were applied throughout this experiment. One week before planting, seeds were mixed with mycorrhiza and in each hill as $10 \mathrm{~g}$ each treatment contains AM alone or mixed with other treatment.

\section{Statistical analysis}

The collected data were arranged in a completely randomized design and replicated four times. Data were statistically analyzed for ANOVA and means compares to fulfill the significance according to Steel and Terrie (1982). Significance level of $\alpha=0.05$ was used in all analysis. 


\section{RESULTS AND DISCUSSION}

\section{Molecular identification of $R$. solani isolates based on ITS}

The identification of $R$. solani isolates using the ITS1 and ITS4 regions, including the 5.8S rDNA gene of the isolates studied (Fig. 1). Rhizoctonia sequences obtained from amplification of conserved ribosomal ITS region (Fig. 2) was compared with sequences from National Center for Biotechnology Information (NCBI) database using BLAST 2.0 (http://www.ncbi.nlm.nih.gov/ BLAST). These sequences were identified and deposited in NCBI GenBank (Table 1). All the isolates identified as $R$. solani.

Table (1). Accession number of $R$. solani isolates on Gene Bank

\begin{tabular}{cc}
\hline Isolate code & Gene Bank Accession no. \\
\hline Rs01 & MH687911 \\
Rs02 & MH687912 \\
Rs03 & MH687913 \\
Rs04 & MH687914 \\
Rs05 & $M H 687915$ \\
Rs06 & $M H 687916$ \\
\hline
\end{tabular}

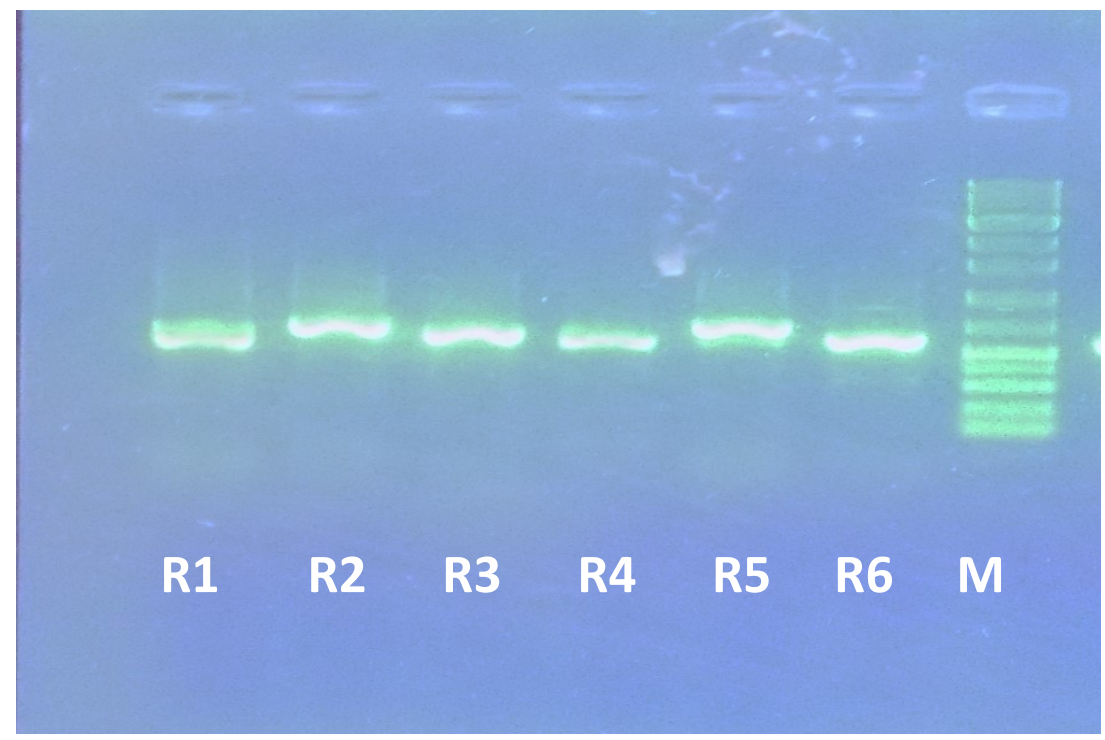

Fig. (1). DNA profile generated by ITS primers on Rhizoctonia solani isolates; R1=Alexandria, R2= Beheira, R3= Beni Suef, R4= Faiyum, R5= Monufia, R6= Kafar Elsheikh, M=100bp marker. 


\section{>Rs01}

tcattattga attnatgtag agtttggttg tagctggctc ctaattaaac ttgggggcat gtgcacacct ttctctttca tcccatacac acctgtgcac ctgtgagaca gatgtttgt gggggggaag gaactttatt ggaccttcta ctccccctng acttctgtct acttaattca tataaactca atttattta aaacggatgt aatggatgta acacatctaa tactaagttt caacaacgga tctcttggct ctcgcatcga tgaagaacgc agcgaaatgc gataagtaat gtgaattgca gaattcagtg aatcatcgaa tcttgaacg caccttgcgc tccttggtat tccttggagc atgcctgttt gagtatcatg aaatcttcaa agtcaaacct tttgttaatt caattggttc tgcttggta ttggaggatt attgcagctt cacacctgct cctcttgtg cattagctgg atctcagtgt tatgcttggt tccactcagc gtgataagtt atctatcgct gaggacaccc tgttaaaaag gggtggccaa ggtaaatgca gatgaaccgc ttctaatagt ccattgactt ggacaatatc taatttatga tctgatctca aatc

\section{$>$ Rs02}

aaggatcatt attgaattaa tgtagagttt ggttgtagct ggctcctaat taaacttggg ggcatgtgca cacctttctc ttcatccca tacacacctg tgcacctgtg agacagatgt ttgtggggg ggaaggaact ttattggacc ttctactccc ccttgacttc tgtctactta attcatataa actcaattta ttttaaaacg gatgtaatgg atgtaacaca tctaatacta agttcaaca acggatctct tggctctcgc atcgatgaag aacgcagcga aatgcgataa gtaatgtgaa ttgcagaatt cagtgaatca tcgaatcttt gaacgcacct tgcgctcctt ggtattcctt ggagcatgcc tgttgagta tcatgaaatc ttcaaagtca aacctttgt taattcaatt ggttctgctt tggtattgga ggattattgc agcttcacac ctgctcctct ttgtgcatta gctggatctc agtgttatgc ttggttccac tcagcgtgat aagttatcta tcgctgagga caccctgtta aaaaggggtg gccaaggtaa atgcagatga accgcttcta atagtccatt gacttggaca atatctaatt tatgatctga tctcaaa

\section{$>\mathrm{Rs03}$}

tcattattga attnatgtag agttggttg tagctggctc ctaattaaac ttgggggcat gtgcacacct ttctcttca tcccatacac acctgtgcac ctgtgagaca gatgtttgt gggggggaag gaactttatt ggaccttcta ctccccctng acttctgtct acttaattca tataaactca atttattta aaacggatgt aatggatgta acacatctaa tactaagttt caacaacgga tctcttggct ctcgcatcga tgaagaacgc agcgaaatgc gataagtaat gtgaattgca gaattcagtg aatcatcgaa tcttgaacg caccttgcgc tccttggtat tccttggagc atgcctgttt gagtatcatg aaatcttcaa agtcaaacct tttgttaatt caattggttc tgcttggta ttggaggatt attgcagctt cacacctgct cctcttgtg cattagctgg atctcagtgt tatgcttggt tccactcagc gtgataagtt atctatcgct gaggacaccc tgttaaaaag gggtggccaa ggtaaatgca gatgaaccgc ttctaatagt ccattgactt ggacaatatc taatttatga tctgatctca aatc

\section{$>\mathrm{Rs} 04$}

tcattattga attnatgtag agtttggttg tagctggctc ctaattaaac ttgggggcat gtgcacacct ttctctttca tcccatacac acctgtgcac ctgtgagaca gatgtttgt gggggggaag gaactttatt ggaccttcta ctccccctng acttctgtct acttaattca tataaactca atttattta aaacggatgt aatggatgta acacatctaa tactaagtt caacaacgga tctcttggct ctcgcatcga tgaagaacgc agcgaaatgc gataagtaat gtgaattgca gaattcagtg aatcatcgaa tctttgaacg caccttgcgc tccttggtat tccttggagc atgcctgttt gagtatcatg aaatcttcaa agtcaaacct tttgttaatt caattggttc tgcttggta ttggaggatt attgcagctt cacacctgct cctcttgtg cattagctgg atctcagtgt tatgcttggt tccactcagc gtgataagtt atctatcgct gaggacaccc tgttaaaaag gggtggccaa ggtaaatgca gatgaaccgc ttctaatagt ccattgactt ggacaatatc taatttatga tctgatctca aatc 


\section{$>$ Rs05}

aattaaactt gggggcatgt gcacaccttt ctcttcatc ccatacacac ctgtgcacct gtgagacaga tgtttgtgg gggggaagga actttattgg accttctact ccccttgac ttctgtctac ttaattcata taaactcaat ttattttaaa acggatgtaa tggatgtaac acatctaata ctaagtttca acaacggatc tcttggctct cgcatcgatg aaraacgcag cgaaatgcga taagtaatgt gaattgcaga attcagtgaa tcatcgaatc tttgaacgca ccttgcgctc cttggtattc cttggagcat gcctgtttga gtatcatgaa atcttcaaag tcaaaccttt tgttaattca attggttctg cttggtatt ggaggattat tgcagcttca cacctgctcc tcttgtgca ttagctggat ctcagtgtta tgcttggttc cactcagcgt gataagttat ctatcgctga ggacaccctg ttaaaaaggg gtggccaagg taaatgcaga tgaaccgctt ctaatagtcc attgacttgg acaatatcta atttatgatc tgatctcaaa tcaggtagga ctacccgctg aacttaagca tatcaataag $\mathrm{c}$

\section{$>$ Rs06}

tagctggctc ctaattaaac ttgggggcat gtgcacacct ttctctttca tcccatacac acctgtgcac ctgtgagaca gatgtttgt gggggggaag gaactttatt ggaccttcta ctccccttg acttctgtct acttaattca tataaactca atttatttta aaacggatgt aatggatgta acacatctaa tactaagttt caacaacgga tctcttggct ctcgcatcga tgaagaacgc agcgaaatgc gataagtaat gtgaattgca gaattcagtg aatcatcgaa tcttgaacg caccttgcgc tccttggtat tccttggagc atgcctgttt gagtatcatg aaatcttcaa agtcaaacct tttgttaatt caattggttc tgcttggta ttggaggatt attgcagctt cacacctgct cctcttgtg cattagctgg atctcagtgt tatgcttggt tccactcagc gtgataagtt atctatcgct gaggacacc tgttaaaaag gggtggccaa ggtaaatgca gatgaaccgc ttctaatagt ccattgactt ggacaatatc taatttatga tctgatctca aatcaggtag gactacccgc tgaacttaag $\mathrm{c}$

\section{Fig. (2). Sequence of different isolates of $R$. solani submitted to Gene Bank}

\section{Pathogenicity experiments}

Inoculation of the six tested tomato cultivars; Alia, Freda, Jana, Alesa, Princesa and Alex., was carried out using the tested $R$. solani isolates in greenhouse. Data presented in Table (2) showed disease damping off in all the investigated locations. Frequency of the total isolates from root and stem, were estimated for both isolation techniques in all regions of the six investigated governorates. From the obtained results, all the tested $R$. solani isolates were significantly virulent on susceptible Freda, Alia, Jana and Prencesa cultivars (Infection rates were 71.42, 48.57, 33.33 and 27.61\%, respectively). However, in resistant Alesa and Alex cultivars, infection rates from 24.76 and $19.04 \%$. However, they considerably varied in disease damping off. The highest infection values were obtained by isolate of Beni Suef and the lesser infection values was obtained by isolate from Alexandria, compared with the other tested isolates. 
Table (2). Varietal responses of six tomato cultivars to the tested isolates of $R$. solani

\begin{tabular}{cccc}
\hline \multicolumn{4}{c}{ Infection rate of Pathogen factor (\%) } \\
\hline Isolates & Pre-emergence & Post- emergence & infection \\
\hline Beni Suef & $74.44^{\mathrm{a}}$ & $10.0^{\mathrm{a}}$ & $84.44^{\mathrm{a}}$ \\
Monufia & $50.00^{\mathrm{b}}$ & $7.77^{\mathrm{ab}}$ & $57.77^{\mathrm{b}}$ \\
Beheira & $24.44^{\mathrm{c}}$ & $7.77^{\mathrm{ab}}$ & $32.22^{\mathrm{c}}$ \\
Alexandria & $18.88^{\mathrm{c}}$ & $5.55^{\mathrm{ab}}$ & $24.44^{\mathrm{c}}$ \\
Kafr Elsheikh & $23.33^{\mathrm{c}}$ & $7.77^{\mathrm{ab}}$ & $31.11^{\mathrm{c}}$ \\
Faiyum & $25.55^{\mathrm{c}}$ & $6.66^{\mathrm{ab}}$ & $32.22^{\mathrm{c}}$ \\
Control & $0.00^{\mathrm{d}}$ & $0.00^{\mathrm{b}}$ & $0.00^{\mathrm{d}}$ \\
L.S.D 0.05 & 10.85 & 8.15 & 12.13 \\
\hline \multicolumn{4}{c}{ Infection rate of Tomato cultivar factor (\%) } \\
\hline Cultivar & Pre-emergence & Post- emergence & infection \\
\hline Freda & $60.00^{\mathrm{a}}$ & $11.43^{\mathrm{a}}$ & $71.42^{\mathrm{a}}$ \\
Alia & $40.95^{\mathrm{b}}$ & $7.61^{\mathrm{a}}$ & $48.57^{\mathrm{b}}$ \\
Jana & $27.61^{\mathrm{c}}$ & $5.71^{\mathrm{a}}$ & $33.33^{\mathrm{c}}$ \\
Alex & $20.95^{\mathrm{cd}}$ & $3.80^{\mathrm{a}}$ & $24.76^{\mathrm{cd}}$ \\
Princesa & $21.90^{\mathrm{cd}}$ & $5.71^{\mathrm{a}}$ & $27.62^{\mathrm{cd}}$ \\
Alesa & $14.28^{\mathrm{d}}$ & $4.76^{\mathrm{a}}$ & $19.04^{\mathrm{d}}$ \\
L.S.D 0.05 & 10.04 & 7.55 & 11.23 \\
\hline
\end{tabular}

Values followed by the same letter(s) in each column didn't differ significantly according to Fisher's LSD Test $(P \leq 0.05)$.

\section{The effect of biological control agents on disease incidence}

In order to check the efficacy of the tested biocontrol treatment on controlling damping off disease of tomato plant of resistant, Alesa and susceptible Freda tomato cultivars were treated with AM, T. viride and $B$. subtilus with $R$. solani infection rates was determined in both cultivars at the end of experiments. Results were statistically analyzed and presented in Table (3) obtained in the treatment $T$. viride and $B$. subtilis in agreement with Riad et al. (2016). All tested bioagents reduced the linear growth of $F$. solani. Complete inhibition of the linear growth was obtained with $T$. viride, T. harzianum and $B$. subtilis.

Also, the results obtained in the treatment $T$. viride and AMF agreed with who obtained with Tanwar et al. (2013). The influences of AM fungi ( $G$. intraradices) and Acaulospora laevis $(\mathrm{A})$ with $T$. viride $(\mathrm{T})$ and $P$. fluorescens $(\mathrm{P})$ alone and in combinations on growth of broccoli plants under glasshouse conditions.

This is study was similar with Riad et al. (2016) who reported dry root rot and slow decline diseases of citrus caused by $F$. solani and Tylenchulus semipenetrans, respectively, are serious diseases attacking many groves in Egypt. The most effective treatment against $F$. solani was compost + mixture of $T$. harzianum $+T$. viride which reduced disease incidence and severity by $87.5 \%$. The highest reduction in total count of $F$. solani was obtained with compost + mixture of $T$. harzianum $+T$. viride which reduced total count by $82.1 \%$. 
These results were in agreement with Patro et al. (2018) who reported that during Kharif 2016 and 2017, The disease severity and yield parameters (grain yield and straw yield) were evaluated against banded blight using different combinations of potential biocontrol agents viz., $B$. subtilis, $P$. flourescens and T. asperellum in the field during 2016 and 2017. Among all treatments applied treatment T7 (i.e. Soil application of value added $P$. flourescens $+T$. asperellum $+B$. subtilis (one $\mathrm{kg}$ talc formulation mixed in $25 \mathrm{~kg}$ FYM or vermicompost, incubated for 15 days) applied over an acre at the time of sowing) showed maximum reduction in disease intensity $(22.81 \%)$ and $(50.67$ $\%)$ with higher grain and fodder yield over control. Ainhoa et al., (2010) reported that the AM-inoculated plants were effective in controlling Fusarium wilt, $G$. mosseae - inoculated plants showing the greatest capacity for reduction of disease incidence. The $T$. harzianum-inoculated plants were more effective than AMF-inoculated plants with regard to suppressing disease incidence. Coinoculation of plants with the AMF and $T$. harzianum produced a more effective control of Fusarium wilt than each AMF inoculated alone, but with effectiveness similar to that of $T$. harzianum-inoculated plants.

Table (3). Responses of tomato cultivars treated with biocontrol agents to infection with $R$. solani

\begin{tabular}{|c|c|c|c|}
\hline \multirow{2}{*}{ Treatment } & \multicolumn{3}{|c|}{ Infection percent \% } \\
\hline & Pre-emergence & Post-emergence & Infection \% \\
\hline $\mathrm{AM}+\mathrm{B}+\mathrm{T}^{*}$ & $8.33^{c}$ & $0.00^{\mathrm{b}}$ & $8.33^{\mathrm{c}}$ \\
\hline$B+T$ & $15.00^{\mathrm{bc}}$ & $3.33^{b}$ & $18.33^{\mathrm{bc}}$ \\
\hline $\mathrm{AM}+\mathrm{T}$ & $8.33^{c}$ & $1.66^{b}$ & $10.00^{\mathrm{bc}}$ \\
\hline$A M+B$ & $13.33^{b c}$ & $0.00^{b}$ & $13.33^{\mathrm{bc}}$ \\
\hline $\mathrm{T}$ & $15.00^{\mathrm{bc}}$ & $3.33^{b}$ & $20.00^{\mathrm{bc}}$ \\
\hline B & $18.33^{b c}$ & $5.00^{\mathrm{ab}}$ & $21.66^{b}$ \\
\hline AM & $21.66^{\mathrm{ab}}$ & $0.00^{b}$ & $21.66^{b}$ \\
\hline Control & $31.66^{\mathrm{a}}$ & $10.00^{\mathrm{a}}$ & $41.66^{\mathrm{a}}$ \\
\hline L.S.D 0.05 & 10.30 & 5.61 & 10.90 \\
\hline \multicolumn{4}{|c|}{ Tomato cultivar factor } \\
\hline Cultivar & Pre-emergence & Post-emergence & Infection \% \\
\hline Alesa & $6.25^{\mathrm{b}}$ & $3.75^{a}$ & $8.33^{b}$ \\
\hline Freda & $26.66^{a}$ & $1.25^{\mathrm{a}}$ & $30.41^{\mathrm{a}}$ \\
\hline L.S.D 0.05 & 5.15 & 2.80 & 6.69 \\
\hline \multicolumn{4}{|c|}{ Pathogen factor } \\
\hline Isolate & Pre-emergence & Post-emergence & Infection \% \\
\hline Beni Suef & $29.58^{\mathrm{a}}$ & $3.33^{\mathrm{a}}$ & $32.91^{\mathrm{a}}$ \\
\hline Alexandria & $3.33^{\mathrm{b}}$ & $1.66^{\mathrm{a}}$ & $5.83^{b}$ \\
\hline L.S.D 0.05 & 5.15 & 2.80 & 5.45 \\
\hline
\end{tabular}




\section{REFERENCE}

Abu-Taleb, M. A., K. El-Deeb, and F. O. Al-Otibi (2011). Assessment of antifungal activity of Rumex vesicarius L. and Ziziphus spina-christi (L.) wild extracts against two phytopathogenic fungi. African Journal of Microbiology Research, 5(9):1001-1011.

Alexopoulos, C. J., and C. W. Mims (1979). Introductory Mycology. John Willy and Sons. Inc., New York, Chichester Brisbance, Toronto, Third Edition, 632.

Barnett, H. L. and B. B. Hunter (1987). Illustrated genera of imperfect fungi. 4th Edition. Burgess Publishing Company, Minneapolis, MN, 218 pp.

Booth, C. (1971). The genus Fusarium. The Commonwealth Mycological Institute Kew, Surrey, England, 237pp.

Ellis, M. B. (1971). Dematiaceous Hyphomycetes. Commonwealth Mycological Institute, Kew, England, 608 pp.

Hadwan, H. A. and H. S. Khara (1992). Effect of inoculums level and temperature on the incidence of damping off and root rot tomato by Rhizoctonia solani. Plant Disease Research, 7: 242-244.

Hafez E. E., Hashem M., Balbaa M. M., El-Saadani M. A. and Ahmed S. A. (2013). Induction of new Defensin Genes in Tomato Plants via Pathogens- Biocontrol Agent Interaction. Journal of Plant Pathology \& Microbiology, 4: 167.

Hansen, H. N. (1926). A simple method of obtaining single spore culture. Science, 64: 384.

Khare, A., B. K. Singh and R. S. Upadhyay (2010). Biological control of Pythium aphanidermatum causing damping-off of mustard by mutants of Trichoderma viridae1433. Journal of Agricultural Technology, 6:231-243.

Malibari, A.A.; F.A.AL. Fassi and E.M. Ramadan (1990). Studies on VAmycorrhizal of the western region soil, Saudi Arabia Annals Agric. Sci., Fac. Agric., Ain-Shams Univ., Cairo, Egypt, 35(1): 95-111.

Morsy, M. Ebtsam, K. A. Abdel-Kawi and M. N. A. Khalil (2009). Efficiency of Trichoderma viride and Bacillus subtilis as biocontrol agents against Fusarium solani on tomato plants. Egypt. J. Phytopathol., 37(1):47-57.

Moustafa, S. E.S. and Y. S. Khafagi (1992). Reaction of certain tomato cultivars to Fusarium wilt and root rot diseases caused by Fusarium oxysporium f. sp. lycopersici and Rhizoctonia solani, respectively. Assiut Journal of Agricultural Sciences, 23 (2): 199 - 207.

Mujica, M. I., N. S. M. Cisternas, M. Manzano, J. J. Armesto, and F. Pe'rez. (2016). Relationship between soil nutrients and mycorrhizal associations of two Bipinnula species (Orchidaceae) from central Chile. Annals of Botany, 118:149-158.

Murray, M.G. and W.F. Thompson (1980). Rapid isolation of high molecular weight plant DNA. Nuc. Acids Res. 8:4321-4325

Patro, T.S.S.K., A. Meena, M. Divya and N. Anuradha (2018). Management of banded blight using biological control agents against Rhizoctonia solani Kuhn. In Little millet (Panicum sumatrence). Journal of Pharmacognosy and Phytochemistry, 7 (3): 2664-2667 
Riad S., R. El-Mohamedy, Mostafa M. A. Hammam, Farid Abd-El-Kareem Mahfouz M. and M. Abd-Elgawad (2016). Biological Soil Treatment to Control Fusarium solani and Tylenchulus semipenetrans on Sour Orange Seedlings Under Greenhouse Conditions. International Journal of Chem. Tech. Research coden (USA): IJCRGG, ISSN: 0974-4290, ISSN (Online):2455-9555.

Steel, R. G. D. and J. H. Torrie (1982). Principles and procedures of Statistics. 2nd Ed., McGraw Hill Book Co. Tokyo-Japan.

Tanwar, A., A. Aggarwal, S. Kaushish and S. Chauhan (2013). Interactive Effect of AM Fungi with Trichoderma viride and Pseudomonas fluorescens on Growth and Yield of Broccoli. Plant Protect. Sci., 49 (3): 137-145.

Vincelli P., N. Tisserat (2008). Nucleic acid-based pathogen detection in applied plant pathology. Plant Disease, 92: 660-669.

White, T. J., T. Bruns, S. Lee, J. Taylor (1990). Amplification and direct sequencing of fungal ribosomal RNA genes for phylogenetics. In PCR Protocols: A guide to Methods and Applications. In: M. A. Innis, D. H. Gelfand, J. J. Sninsky \& T. J. White, ed. San Diego, USA: Academic Press, 315-322.

Zouheir Talbi, Mohamed Chliyeh, Btissam Mouria, Abdelaziz El Asri, Fatima Ait Aguil, Amina Ouazzani Touhami, Rachid Benkirane and Allal Douira (2016). Effect of double inoculation with endomycorrhizae and Trichoderma harzianum on the growth of. IJAPBC - Vol. 5(1), Jan Mar, 2016 ISSN: 2277 - 4688. 


\section{الملخص العربي \\ المكافحة الحيوية لمرض الأبول الطرى فى الطماطم المتسبب عن الفطر ريزوكتونيا سولانى}

\section{مصطفى عبد العظيم عامر *، سعد محمود شمه * إسلام أبراهيم أبو السعود*** ،

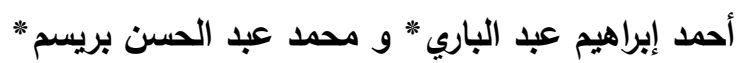

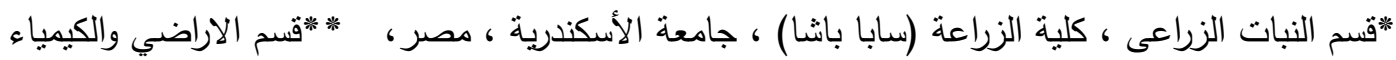

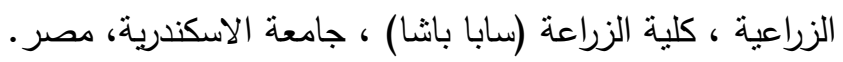

يعثبر مرض الذبول الطري في الطماطم المتسبب عن الفطر ريزوكتونيا سولانى أحد أهم الامراض المدمرة للمحصول فى مصر • نم دراسة تأثير المكافحة الحيوية بإستخدام فطر تريكوديرما فيريدى والميكوريزا الوعائية وبكتيريا باسيلس ستلس لاختبار قدرتهم على مكافحة المرض. طبقا لاختبار إستجابة الأصناف فان جميع عزلات المسبب المرضى ريزوكتونيا سولانى أظهرت أعراض الذبول الطرى فى أصناف الطماطم الستة المختبرة. وقد أظهرت الأختلافات بين الاصناف الستة المختبرة حدوث أعراض ذبول بادرات الطماطم قبل وبعد ظهور البادرات . وقد أظهرت النتائج أن صنف فريدة هو أكثر الاصناف حساسية للإصابة بينما صنف أليسا هو الأكثر مقاومة. وقد

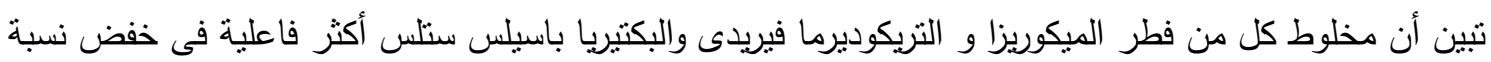
الاصمابة مقارنة بالمعاملات الأخرى. 